\title{
Effect of Zataria multiflora Boiss on haematological and Growth
}

\section{parameters of Oncorhynchus mykiss}

\section{N Choobkar}

Department of Fisheries, College of Agriculture, Kermanshah Branch, Islamic Azad University, Kermanshah, Iran.

Received: August 2017

Accepted: September 2017

\begin{abstract}
Zataria multiflora is well known to middleAccordingly, this result showed that FCR value east, Iran, Afghanistan and Pakistan where, it is cultivated only in warm areas. The objective of this article focused on this issue whether Zataria multiflora Boiss has effect on haematological and Growth parameters of Oncorhynchus mykiss. One hundred and twenty healthy finger ling fish, Oncorhynchus mykiss (mean weight $4.3 \mathrm{~g}$ ) were commercially obtained and then transferred to the research field located in Tehran. Fish were fed on diets

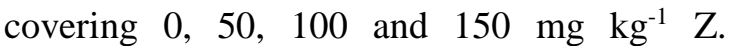
multiflora (Z.M.) as four groups; in triplicates. All of them were hand-fed (3-4\% of body weight) to satiation 6-8 times a day for 8 weeks (60 days). There was no significant difference ( $>0.05$ ) among the fish fed the different levels was minimum in control $(7.20 \pm 0.0)$ with no significant difference $(p>0.05)$ compared with group $50 \mathrm{ppm}$ of Z.M. The result of $\mathrm{WG}$ for group 50 ppm of Z.M. (453.86 \pm 0.46$)$ showed a significant difference $(p<0.05)$ with those of other groups. On the other hand, Z.M. in concentration of $50 \mathrm{ppm}$ could enhance WBC compared to control and other treatments as well as RBC but no difference was observed among the treatments $(p>0.05)$. Against, the values for $\mathrm{Hb}$ and $\mathrm{MCH}$ were significantly lower than others $(p<0.05)$. It is concluded that the fish fed with $50 \mathrm{ppm}$ of Zataria multiflora increased mean weight of rainbow trout while enhancement of innate immunity significantly was occurred.
\end{abstract} of Z.M for the mean weight. The maximum value of SGR was observed in group $50 \mathrm{ppm}$ of Z.M. $(2.85 \pm 0.01)$ with significant difference $(p<0.05)$ with control $(2.44 \pm 0.0)$.

Correspondence: N Choobkar, Department of Fisheries, College of Agriculture, Kermanshah Branch, Islamic Azad University, Kermanshah, Iran. (e-mail: nchoobkar20@iauksh.ac.ir).

Keywords: Oncorhynchus mykiss, Zataria multiflora, Weight, Haematological indices.

\section{Introduction}

Nowadays, application the herbs seems to be the most auspicious strategy in aquaculture for preventing diseases and weight increase of 
fishes (Ardó, Yin, Xu, Váradi, Szigeti, Jeney \& Jeney 2008). Among these herbs, Zataria multiflora is well known to middle-east, Iran, Afghanistan and Pakistan where, it is cultivated only in warm areas (Fazeli, Amin, Attari, Ashtiani, Jamalifar \& Samadi 2007, SaeiDehkordi, Tajik, Moradi \& Khalighi-Sigaroodi 2010). Its Persian name, Avishane Shirazi has been traditionally used and prescribed for flavoring and preserving foods (Fazeli et al. 2007), antibacterial and antioxidant activities (Sharififar, Moshafi, Mansouri, Khodashenas \& Khoshnoodi 2007), inflammatory bowel disease (Nakhai, Mohammadirad, Yasa, Minaie, Nikfar, Ghazanfari, Zamani, Dehghan, Jamshidi \& Boushehri 2007), anti-candidiasis (Mahmoudabadi, Dabbagh \& Fouladi 2007), denture stomatitis treatment (Mahmoudabadi et al. 2007), antitumor activity (Ali, Saleem, Ali \& Ahmad 2000) and antispasmodic effect (Gharib Naseri, Mazlomi, Goshaiesh, Vakilzadeh \& Heidari 2010). Zataria multiflora, a herb belonging to the Laminaceae family has shown nutritional and medicinal properties (Misaghi \& Basti 2007). Carvacrol and Thymol, which are belonging to phenolic constituents and has antibacterial and antifungal activities, are the most important components of $Z$. multiflora essential oil (Ali et al. 2000, Misaghi \& Basti 2007). Results of some investigations as follows showed Increase of survival rate and hatchability of rainbow trout eyed-eggs, immunity enhancement and preventing the bacterial growth such as Staphylococcus aureus in the fillet of salinated fish (Choobkar, Soltani, Ebrahimzadeh Mousavi, Akhonzadeh Basti \& Matinfar 2010), reduction or prevention the fungal infection in rainbow trout eggs (Sharif Roohani 2007), some blood and serum parameters in Acipenser persicus (Sharif Rohani, Masoumzadeh, Haghighi, Jalilpoor, Pourdehghani, Shenavar Masouleh, Alizadeh \& Bazari Moghaddam 2013). These properties could be due to Luteolin (Ali et al. 2000), water-soluble quercetin (Shafiee, Javidnia \& Tabatabai 1999) Terpeneids consists of a mixture of terpenes, oxygenated terpenes, sesquiterpenes and oxygenated sesquiterpenes (Ali et al. 2000, Ebrahimzadeh, Yamini, Sefidkon, Chaloosi \& Pourmortazavi 2003, Misaghi \& Basti 2007).

The objective of this article focused on this issue whether Zataria multiflora Boiss has effect on haematological and Growth parameters of Oncorhynchus mykiss.

\section{Materials and Methods}

Fish

One hundred and twenty healthy finger ling fish, Oncorhynchus mykiss (mean weight $4.3 \mathrm{~g}$ ) were commercially obtained from a private sector in Tehran, Iran. They were then transferred to the research field located in Biotechnology Institute in Tehran, where was designed by our research team. The fish addaptated in a holding veniro prefilled with a well water for two weeks before experiment.

They were randomly distributed among twelve 2000-L high density polyethylene (HDPE) tanks at a density of 10 fish each. The tanks were prefilled with $400 \mathrm{~L}$ of clean wellaerated well-water (120 $\mathrm{L} \mathrm{h}^{-1}$ of flow rate). The water was maintained at $15.5^{\circ} \mathrm{C}$, dissolved 
oxygen $7.5 \mathrm{mg} \mathrm{L}^{-1}, \mathrm{pH}$ 8.1. Fish were fed on diets covering $0,50,100$ and $150 \mathrm{mg} \mathrm{kg}^{-1} Z$. multiflora (Z.M.) as four groups; in triplicates. All of them were hand-fed (3-4\% of body weight) to satiation 6-8 times a day for 8 weeks (60 days).

\section{Experimental diet and herbal extract}

fish food was prepared based on the method of Kakoolaki, Akbary, Zorriehzahra, Salehi, Sepahdari, Afsharnasab, Mehrabi and Jadgal (2016) with the basis of the Kimiagaran-eTaghzieh company (protein $42-46 \%$, fat $15 \%$, fiber $1.5-2.5 \%, 10 \%$ ash, $10 \%$ moisture content). The Z.M. powder was then added to the basal control diet with spraying of olive oil, to obtain 4 different treatments as 0.0 (Control group) 50, 100 and $150 \mathrm{mg} \mathrm{kg}^{-1}$ of Z.M. The prepared food was kept in refrigerator until use.

\section{Sampling approach}

The fish were sampled at the beginning, midperiod (only for weighing of fish) and at the end of the experiment to determine the values of growth factors and blood parameters throughout the course.

\section{Growth performance}

The initial, mid-course and final (60 days) weights of 3 fish in each treatment and replication were applied to evaluate growth performance based on the method of (Kakoolaki et al. 2016) as follows:

$$
\mathrm{WG}(\%)=\mathrm{Wf}-\mathrm{Wi} / \mathrm{Wi} \times 100
$$

: Where, WG was weight gain and mean value of final body weight (Wf) of each group was measure by dividing total fish weight in each tank by number of fish.

DGI $(\%)=([(W G \times 100) /(W i+W f) / 2)] / t$

: Where, DGI, Wi and Wf were daily growth index, initial and final values of fish weight, respectively.

$$
\mathrm{FCR}=\frac{\text { feed given (dry weight) }}{\text { body wt. } \times \text { WG (wet weight) }}
$$

: Where, FCR was feed conversion ratio.

\section{Blood sampling}

Fish were anaesthetized by immersing in the water containing $30 \mathrm{ppm}$ of clove powder. Blood was sampled from the caudal puncture of 3 fish caught at random from each group and replication 8 weeks after the start of the feeding using $1 \mathrm{~mL}$ heparinated syringe to evaluate hamatocrit and differential white blood count (Abd-El-Rhman 2009) connected to 24-gauge needles.

Blood slides were introduced to NattHerrick's solution (1:200) to stained and count RBC $\left(10^{6} \mathrm{~mm}^{-3}\right)$ and white blood cells (WBC) $\left(10^{4} \mathrm{~mm}^{-3}\right)$ (Grant 2015) although the procedure employed to calculate occurrence of these two blood cells was different as above-sentence mentioned. Blood slides stained with Giemsa solution were organized for differential WBC counts (\%). Therefore, One hundred leukocytes as well as Lymphocytes, Monocytes, Neutrophil and Eosinophil from each stained slide, were counted using a light microscope.

For hematocrit measurements, heparinized tubes were centrifuged for 3 minutes at 13000 $\times \mathrm{g}$, and the result solution was then measured 
by hematocrit scale reader (Řehulka 2000).

Hemoglobin was also measured by photometric assay cyanomethemoglobin approach (Kakoolaki et al., 2016) so that a $20 \mu l$ blood sample was drawn from a heparinized capillary tube, mixed in $5.0 \mathrm{ml}$ of cyanhemoglobin reagent (Hycel) and read the absorbance values at $540 \mathrm{~nm}$ using a spectrophotometer. The calculation method for other blood parameters is as follows:

$$
\begin{aligned}
& \operatorname{MCV}(\mathrm{fL})=\frac{[(\mathrm{Hct}, \%) \times 10]}{\left(\mathrm{RBC}, 10^{6} \text { per } \mathrm{mm}^{3}\right)} \\
& \operatorname{MCH}\left(\text { pg cell }{ }^{-1}\right)=\frac{\left[\left(\mathrm{Hb}, \mathrm{g} \mathrm{dL}^{-1}\right) \times 10\right]}{\left(\mathrm{RBC}, 10^{6} \text { per } \mathrm{mm}^{3}\right)} \\
& \operatorname{MCHC}(\%)=\frac{\left[\left(\mathrm{Hb}, \mathrm{g} \mathrm{dL}^{-1}\right) \times 100\right]}{(\mathrm{Hct}, \%)}
\end{aligned}
$$

\section{Results}

The average weights of rainbow trout affected by Z.M. are listed in Table 1. There was no significant difference $(p>0.05)$ among the fish fed the different levels of Z.M for the mean weight. At the mid time of the experiment, the maximum and minimum mean weights $(17.73 \pm$ $0.48,13.40 \pm 0.48)$ were belonged to Z.M. (150 ppm) and control groups (Table 1, Fig. 1). The mean value of fish fed different levels of supplemented diet with Z.M. showed a significant difference $(p<0.05)$ as well as the final weight after 60 days. Accordingly, the maximum and minimum mean weights $(23.30 \pm$ $0.48,18.83 \pm 0.48$ ) were belonged to Z.M., 100 ppm and control groups (Table 1, Fig. 1).

Table 1. Estimated marginal mean of weigh of the sampled rainbow trout in different levels of Zataria multiflora in determined sampling times

\begin{tabular}{lll}
\hline Weeks & groups & \\
& & Mean \pm SEM \\
\cline { 2 - 3 } 1 & 1 & $4.33 \pm 0.48$ \\
1 & 2 & $4.30 \pm 0.48$ \\
1 & 3 & $4.30 \pm 0.48$ \\
1 & 4 & $4.33 \pm 0.48$ \\
\hline 4 & 1 & $13.40 \pm 0.48^{\mathrm{a}}$ \\
4 & 2 & $15.03 \pm 0.48^{\mathrm{b}}$ \\
4 & 3 & $15.56 \pm 0.48^{\mathrm{b}}$ \\
4 & 4 & $17.73 \pm 0.48^{\mathrm{c}}$ \\
\hline 8 & 1 & $18.83 \pm 0.48^{\mathrm{a}}$ \\
8 & 2 & $23.30 \pm 0.48^{\mathrm{b}}$ \\
8 & 3 & $20.93 \pm 0.48^{\mathrm{c}}$ \\
8 & 4 & $19.90 \pm 0.48^{\mathrm{a}}$ \\
\hline
\end{tabular}

In each sectioned column, no significant difference was observed in similar superscripts. 


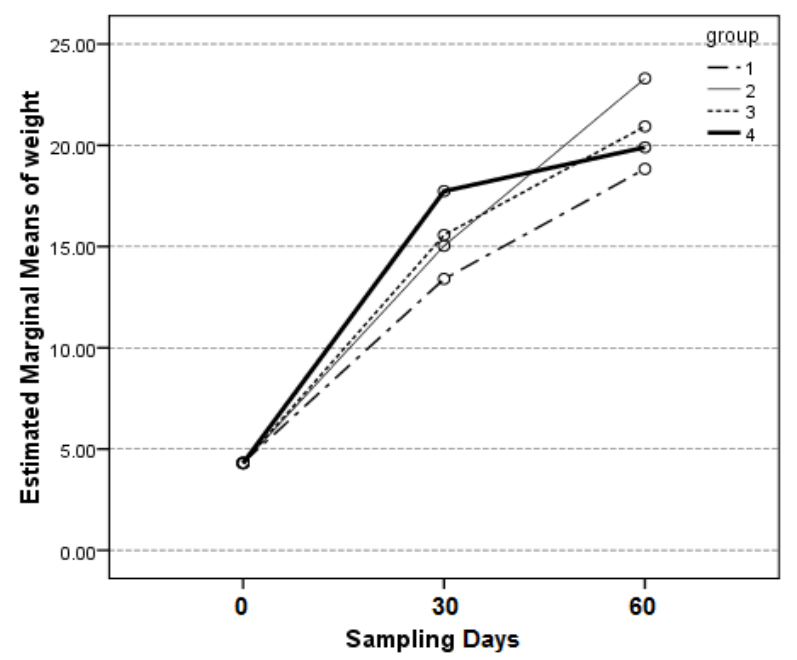

Figure 1. The trend of mean weight of sampled fish in different groups of Zataria multiflora.

Growth parameters and the group comparison among the different level of Z.M. are listed in Table 2. As a result, each of the growth indices containing SGR, FCR and WG were significantly different $(p<0.05)$ among the Z.M. levels. The maximum value of SGR was observed in group 50 ppm of Z.M. $(2.85 \pm 0.01)$ with significant difference $(p<0.05)$ with control $(2.44 \pm 0.0)$. There was no significant difference ( $p>0.05$ ) between control and groups 100 and $150 \mathrm{ppm}$ of Z.M. Accordingly, this result showed that FCR value was minimum in control
$(7.20 \pm 0.0)$ with no significant difference ( $p>$ $0.05)$ compared with group $50 \mathrm{ppm}$ of Z.M. The maximum value $(8.40 \pm 0.0)$ was observed in group of $150 \mathrm{ppm}$ Z.M. with significant difference $(p<0.05)$ compared with control. The result of WG for group $50 \mathrm{ppm}$ of Z.M. (453.86 \pm 0.46$)$ showed a significant difference ( $p<0.05)$ with those of other groups. The WG of the control group $(330.06 \pm 2.84)$ was the least. The values of FCR (Table 3) showed no considerable difference $(p>0.05)$ between levels of control and 50 ppm of Z.M.

Table 2. The average value (Mean \pm SEM) for growth parameters affected by different levels of Zataria multiflora

\begin{tabular}{llll}
\hline \multirow{3}{*}{ SGR } & groups & Mean \pm SEM & P value \\
\cline { 2 - 4 } & Control & $2.44 \pm 0.00^{\mathrm{a}}$ & 0.0 \\
& $50 \mathrm{ppm}$ & $2.85 \pm 0.01^{\mathrm{b}}$ & \\
& $100 \mathrm{ppm}$ & $2.64 \pm 0.00^{\mathrm{a}}$ & \\
& $150 \mathrm{ppm}$ & $2.55 \pm 0.00^{\mathrm{a}}$ & \\
\hline FCR & Control & $7.20 \pm 0.0^{\mathrm{a}}$ & 0.0 \\
& $50 \mathrm{ppm}$ & $7.24 \pm 0.0^{\mathrm{a}}$ & \\
& $100 \mathrm{ppm}$ & $8.20 \pm 0.0^{\mathrm{b}}$ & \\
\hline WG $(\%)$ & $150 \mathrm{ppm}$ & $8.40 \pm 0.0^{\mathrm{b}}$ & \\
& Control & $330.06 \pm 2.84^{\mathrm{a}}$ & 0.0 \\
& $50 \mathrm{ppm}$ & $453.86 \pm 0.46^{\mathrm{b}}$ & \\
& $100 \mathrm{ppm}$ & $389.90 \pm 0.85^{\mathrm{c}}$ & \\
& $150 \mathrm{ppm}$ & $362.32 \pm 0.24^{\mathrm{a}}$ & \\
\hline
\end{tabular}


The variation of the haematological indices affected by different level of $Z$. multiflora is given in Table 3. Accordingly and based on the WBC and $\mathrm{RBC}$ results, there were no significant difference among the grouped Z. multiflora ( $p=$ $0.28, p=0.37$, respectively). Based on this result, Hemoglobin was experimentally went up ( $p=0.00$ ) in dose-dependent manner so that the mean values of control was $10.10 \pm 0.15$ less than those of the 50, 100 and 150 ppm groups, which respectively showed $11.40 \pm 1.15,13.00 \pm 0.58$ and $13.40 \pm$ 0.26 . No significant difference $(p>0.05)$ was observed between the value of $\mathrm{Hb}$ for group 100 and $150 \mathrm{ppm}$. Hematocrit showed no significant difference among the Z.M. groups so that the least value $(25.23 \pm 1.06)$ was dedicated to the control group with no significance difference $(p>0.05)$ with the highest value $(26.90 \pm 2.93)$ in group 50 ppm Z.M. supplemented diet (Table 3). The mean value of $\mathrm{MCV}$ showed that the minimum measurement (96.66 \pm 14.76$)$ belonged to Z.M. $150 \%$ supplemented diet (table 3 ) while that of the maximum $(104.63 \pm 29.80)$ presented in group 50 ppm of Z.M. As a result of stated in table 3 there was no significant difference $(p>0.05)$ among the fish fed Z.M. supplemented diet but functionally the MCV values showed considerable differences among the groups. The Values of $\mathrm{MCH}$ and MCHC showed no significant difference $(p>0.05)$ among the different groups affected by different Z.M. The maximum values for $\mathrm{MCH}$ and $\mathrm{MCHC}$ were $60.885 \pm 9.63$ (control) and 52.35 $\pm 3.82(150$ ppm) and those of minimum values were $43.27 \pm$ 8.33 (50 ppm) and $43.63 \pm 5.77$ (50 ppm).

Table 3. The average percent (Mean \pm SEM) for haematological parameters affected by different levels of Zataria multiflora

\begin{tabular}{|c|c|c|c|}
\hline & groups & Mean \pm SEM & $\mathrm{P}$ value \\
\hline \multirow{4}{*}{ WBC $\left(10^{4}\right)$} & Control & $4.63 \pm 0.26$ & 0.28 \\
\hline & $50 \mathrm{ppm}$ & $5.33 \pm 0.49$ & \\
\hline & 100 ppm & $4.39 \pm 0.24$ & \\
\hline & $150 \mathrm{ppm}$ & $4.28 \pm 0.44$ & \\
\hline \multirow[t]{4}{*}{$\operatorname{RBC}\left(10^{6}\right)$} & Control & $1.73 \pm 0.23$ & 0.37 \\
\hline & $50 \mathrm{ppm}$ & $2.83 \pm 0.52$ & \\
\hline & 100 ppm & $2.80 \pm 0.51$ & \\
\hline & 150 ppm & $2.86 \pm 0.64$ & \\
\hline \multirow[t]{4}{*}{$\mathrm{Hb}\left(\mathrm{g} \mathrm{dL}^{-1}\right)$} & Control & $10.10 \pm 0.15^{\mathrm{a}}$ & 0.000 \\
\hline & $50 \mathrm{ppm}$ & $11.40 \pm 1.15^{\mathrm{b}}$ & \\
\hline & 100 ppm & $13.00 \pm 0.58^{c}$ & \\
\hline & $150 \mathrm{ppm}$ & $13.40 \pm 0.26^{\mathrm{c}}$ & \\
\hline \multirow[t]{4}{*}{ Hct (\%) } & Control & $25.23 \pm 1.06$ & 0.94 \\
\hline & $50 \mathrm{ppm}$ & $26.90 \pm 2.93$ & \\
\hline & 100 ppm & $26.40 \pm 1.90$ & \\
\hline & $150 \mathrm{ppm}$ & $25.83 \pm 1.73$ & \\
\hline \multirow[t]{4}{*}{$\mathrm{MCV}(\mathrm{FL})$} & Control & $150.96 \pm 21.44$ & 0.32 \\
\hline & $50 \mathrm{ppm}$ & $104.63 \pm 29.80$ & \\
\hline & 100 ppm & $100.43 \pm 18.74$ & \\
\hline & $150 \mathrm{ppm}$ & $96.66 \pm 14.76$ & \\
\hline \multirow[t]{4}{*}{$\mathrm{MCH}\left(\mathrm{pg} \mathrm{cell}^{-1)}\right.$} & Control & $60.885 \pm 9.63$ & 0.70 \\
\hline & $50 \mathrm{ppm}$ & $43.27 \pm 8.33$ & \\
\hline & 100 ppm & $50.44 \pm 11.52$ & \\
\hline & $150 \mathrm{ppm}$ & $51.72 \pm 11.51$ & \\
\hline \multirow[t]{4}{*}{$\mathrm{MCHC}(\%)$} & Control & $40.20 \pm 2.16$ & 0.18 \\
\hline & $50 \mathrm{ppm}$ & $43.63 \pm 5.77$ & \\
\hline & 100 ppm & $49.54 \pm 2.67$ & \\
\hline & $150 \mathrm{ppm}$ & $52.35 \pm 3.82$ & \\
\hline
\end{tabular}


As a result, Table 4 shows Z. M. with the different levels had no any effect $(p=0.22)$ on lymphocyte quantity, which the values of the maximum amount occurred in group $100 \mathrm{ppm}$ of Z.M. (78.30 \pm 0.47$)$ was not statistically different $(p>0.05)$ from the least value of lymphocyte in control (76.20 \pm 0.58). Accordingly, Eosinophil quantity was not shown any difference ( $p>0.05)$ among the different groups, from the least $(0.40 \pm 0.23)$ for group of $100 \mathrm{ppm}$ of Z.M. up to those of others. The mean value of neutrophil was statistically increased in group $50 \mathrm{ppm}$ of Z. M. (11.03 \pm $0.12)$ compared with control $(9.10 \pm 0.41)$, which it showed no significant difference ( $p>$ 0.05) with other groups (Table 4).

Table 4. The average percent (Mean \pm SEM) for differentiated WBC affected by different levels of Zataria multiflora

\begin{tabular}{llll}
\hline & groups & Mean \pm SEM & P value \\
\cline { 2 - 4 } Lymphocyte \% & Control & $76.20 \pm 0.58$ & 0.22 \\
& $50 \mathrm{ppm}$ & $76.50 \pm 0.75$ & \\
& $100 \mathrm{ppm}$ & $78.30 \pm 0.47$ & \\
& $150 \mathrm{ppm}$ & $77.46 \pm 0.93$ & \\
\hline Monocyte \% & Control & $14.23 \pm 0.29^{\mathrm{a}}$ & 0.03 \\
& $50 \mathrm{ppm}$ & $12.00 \pm 0.70^{\mathrm{b}}$ & \\
& $100 \mathrm{ppm}$ & $12.10 \pm 0.28^{\mathrm{b}}$ & \\
& $150 \mathrm{ppm}$ & $13.36 \pm 0.58^{\mathrm{a}}$ & \\
\hline Neutrophil \% & Control & $9.10 \pm 0.41^{\mathrm{a}}$ & 0.001 \\
& $50 \mathrm{ppm}$ & $11.03 \pm 0.12^{\mathrm{b}}$ & \\
& $100 \mathrm{ppm}$ & $9.20 \pm 0.17^{\mathrm{a}}$ & \\
& $150 \mathrm{ppm}$ & $8.70 \pm 0.23^{\mathrm{a}}$ & \\
\hline Eosinophil \% & Control & $0.46 \pm 0.13$ & 0.98 \\
& $50 \mathrm{ppm}$ & $0.46 \pm 0.03$ & \\
& $100 \mathrm{ppm}$ & $0.40 \pm 0.23$ & \\
& $150 \mathrm{ppm}$ & $0.46 \pm 0.16$ & \\
\hline
\end{tabular}

\section{Discussion}

According to results of growth indices (Table $2)$, there was an appropriate effect of $50 \mathrm{ppm}$ Z.M. on specific growth rate in comparison with other levels of Z.M. (0, 100 and 150 $\mathrm{ppm})$. The result of $\mathrm{WG}$ confirmed this former finding so that WG (\%) of group $50 \mathrm{ppm}$ of Z.M. (453.86 \pm 0.46$)$ was the maximum showed a significant difference $(p<0.05)$ with those of other groups. As control group showed the least value of WG indicating on the effect of Z.M. with minimum level on growth while the FCR showed no significant difference in level of $50 \mathrm{ppm}$ of Z.M. compared with control but other groups.

There was no evidence to believe that $Z$. multiflora can experimentally effect on the mean value of $\mathrm{WBC}$ and RBC (table 3). This result showed that $\mathrm{Hb}$ can increasingly affect due to Z.M. Roche and Bogé (1996) showed that $\mathrm{Hb}$ value increases through the environmental factors and chemical intoxication. Grant (2015) presented that $\mathrm{Hb}$ 
can increase due to induced starvation and variation in water temperature and decrease because of infection (Harikrishnan, Rani \& Balasundaram 2003) or as a result of the swelling of RBC as well as weak transfer of hemoglobin from the hematopoeitic tissues. As a result of a study carried out in rainbow trout, the maximum mean value of RBC was observed in group 100 ppm of Z.M. (Akbary, Ghareghani poor \& Fereidouni 2015) but in this study, there was no a significant difference was observed among the groups, 50, 100 and $150 \mathrm{ppm}$ of Z.M. Similar to this results, the $\mathrm{RBC}$ value in the study was made by Akbary et al. (2015) showed no remarkable difference was shown among the above 3 mentioned treatments. Dislike to this result; Soltani, Sheikhzadeh, Ebrahimzadeh-Mousavi and Zargar (2010) showed an increase trend in WBC affected by Z.M. up to 60 ppm Z.M. supplemented diet while it decreased after increasing Z.M. concentration. our result indicated on a slight increase of $\mathrm{Hb}$ due to Z.M. Decreased hemoglobin concentration, $\mathrm{RBC}$ and hematocrit values point out that RBCs are being demolished by the leucocytosis activity in an erythrocytic anemia with subsequent erythroblastosis (Haney, Hursh, Mix \& Winton 1992). Presence of immature erythrocytes in outlying blood can be due to infection or younger fish result in decrease of hemoglobin (Walsh \& Luer 2004).

Choobkar, Kakoolaki, Rezaeimanesh, Mohammadi and Safar Khanloo (2017) presented that 100 ppm of Z.M. can enhance the hemoglobin value in Cyprinus carpio. The packed cell volume (Hematocrit) counts is an indicator for fish health prognosis (Harikrishnan et al. 2003). The measurement less than $20 \%$ in teleosts usually are associated with anemia (Clauss, Dove \& Arnold 2008). An upsurge in hematocrit value was stated because of oxygen depletion (Holeton \& Randall 1967). Hematocrit increased in dosedependent manner in $C$. carpio diet supplemented with Z.M. with no significant (Choobkar et al. 2017). In another study (Ngugi, Oyoo-Okoth, Mugo-Bundi, Orina, Chemoiwa \& Aloo 2015) Hct increased from $40 \%$ up to $90 \%$ in Lobeo victorianus fed with the herb, Urtica dioica after 16 weeks in dosedependent manner. Baba, Acar, Yılmaz, Öntaş and Kesbiç (2017) stated hematocrit was not affected due to argan oil or other dietary lipid sources. Mohseni, Pourali, Kazemi and Bai (2014) showed that increase protein from 30 up to $50 \%$ as supplemented diet can grow Hct of Huso huso juvenile. Juvenile teleosts have notably higher lymphocyte and total leukocyte counts compared with adults (Clauss et al. 2008) against this finding showed no significant changes in juvenile fishes. Young fish and herbal medicines may increase WBC (Grant 2015, Kakoolaki et al. 2016). Simultaneous increase of WBC and neutrophil count maybe indicated on inflammatory or other condition of the fish while rainbow trout is reared in summer or spring or confront with stress (Harikrishnan et al. 2003).

As indicator for specific immunity, this result showed no any effectiveness of Z. M. on the values of Lymphocyte and eosinophil among the different levels of Z. M. Based on 
the indication of non-specific immunity, the fish fed supplemented diet with $50 \mathrm{ppm}$ of $\mathrm{Z}$. M. showed more effectiveness for neutrophil. Monocyte values for the fish fed with 50 and $100 \mathrm{ppm}$ of Z.M. showed lower values compared to $150 \mathrm{ppm}$ and control groups.

In the study conducted by Soltani et al. (2010), blood lymphocyte value was increased in fish, C. carpio fed Z. multiflora. They did not explain the mechanism involved lymphocyte increasing. Similar to their finding, IgM and neutrophil were significantly increased in the rat fed supplemented diet mixed with Z. multiflora (Dehkordi, Dehkordi, Chaleshtori, Khamesipour \& Katsande 2015). This finding is against of this result showed a decrease of lymphocyte count in rainbow trout. Raissy, Fakhrian, Jafarian and Varshoei (2014) showed an increase in value of neutrophil when starlet fish (Acipenser ruthenus) fed Z. multiflora. Our results showed no effectiveness of Z.M. on specific immunity observed in the result of lymphocyte values shown in table 4.

The result of growth indices showed the use of Zataria multiflora has no economic efficiency in concentration of 100 and 150 ppm. Accordingly, as a result of differentiate WBC, use of $50 \mathrm{ppm}$ of Z. multiflora significantly increases Neutrophil as nonspecific haematological cell. It is concluded that the fish fed with $50 \mathrm{ppm}$ of Zataria multiflora increased mean weight of rainbow trout while enhancement of innate immunity significantly was occurred.

\section{References}

Abd-El-Rhman, A.M. (2009) Antagonism of Aeromonas hydrophila by propolis and its effect on the performance of Nile tilapia, Oreochromis niloticus. Fish \& shellfish immunology 27 (3), 454-459.

Akbary, P., Ghareghani poor, M. \& Fereidouni, M.S. (2015) Lextracts pulegium Mentha and Zataria multiflora Boiss of Effects of Cells Blood and Burst respiratory, Lysozyme, Phagocytosis on (Oncorhynchus mykiss Walbaum (Rainbow trout). Journal of Veterinary Research 70 (4), 447-454.

Ali, M.S., Saleem, M., Ali, Z. \& Ahmad, V.U. (2000) Chemistry of zataria multiflora (lamiaceae). Phytochemistry 55 (8), 933-936.

Ardó, L., Yin, G., Xu, P., Váradi, L., Szigeti, G., Jeney, Z. \& Jeney, G. (2008) Chinese herbs (Astragalus membranaceus and Lonicera japonica) and boron enhance the non-specific immune response of Nile tilapia (Oreochromis niloticus) and resistance against Aeromonas hydrophila. Aquaculture 275 (1), 26-33.

Baba, E., Acar, Ü., Y1lmaz, S., Öntaş, C. \& Kesbiç, O.S. (2017) Pre-challenge and postchallenge haemato-immunological changes in Oreochromis niloticus (Linnaeus, 1758) fed argan oil against Lactococcus garvieae. Aquaculture Research.

Choobkar, N., Kakoolaki, S., Rezaeimanesh, M., Mohammadi, F. \& Safar Khanloo, L. (2017) Effects of Supplementation of powdered Zataria multiflora on growth, serum and haemotological indicators in common carp 
(Cyprinus carpio). Veterinary Clinical Pathology 11 (2), 127-141 (In Persian).

Choobkar, N., Soltani, M., Ebrahimzadeh Mousavi, H.A., Akhonzadeh Basti, A. \& Matinfar, A. (2010) Effect of Zataria multiflora Boiss essential oil on the growth of Staphylococcus aureus in the light salted fillets of silver carp (Hypophthalmichthys molitrix). Iranian Journal of Fisheries Sciences 9 (3), 352-359.

Clauss, T.M., Dove, A.D. \& Arnold, J.E. (2008) Hematologic disorders of fish. Veterinary clinics of North America: Exotic animal practice 11 (3), 445-462.

Dehkordi, H.S., Dehkordi, M.J., Chaleshtori, M.R., Khamesipour, F. \& Katsande, S. (2015) Effect of alcohol extract of Zataria multiflora (Boiss), Satureja bachtiarica (Bunge) and Zaravschanica membranacea (Boiss) on immuno-hematologic factors in rats. Tropical Journal of Pharmaceutical Research 14 (11), 1999-2004.

Ebrahimzadeh, H., Yamini, Y., Sefidkon, F., Chaloosi, M. \& Pourmortazavi, S.M. (2003) Chemical composition of the essential oil and supercritical $\mathrm{CO} 2$ extracts of Zataria multiflora Boiss. Food Chemistry 83 (3), 357-361.

Fazeli, M.R., Amin, G., Attari, M.M.A., Ashtiani, H., Jamalifar, H. \& Samadi, N. (2007) Antimicrobial activities of Iranian sumac and avishan-e shirazi (Zataria multiflora) against some food-borne bacteria. Food control 18 (6), 646-649.
Gharib Naseri, M., Mazlomi, H., Goshaiesh, M., Vakilzadeh, G. \& Heidari, A. (2010) Antispasmodic effect of Zataria multiflora Boiss. Leaf extract on the rat uterus. Iranian Journal of Pharmaceutical Research, 131136.

Grant, K.R. (2015) Fish hematology and associated disorders. Veterinary Clinics of North America: Exotic Animal Practice 18 (1), 83-103.

Haney, D., Hursh, D., Mix, M. \& Winton, J. (1992) Physiological and hematological changes in chum salmon artificially infected with erythrocytic necrosis virus. Journal of Aquatic Animal Health 4 (1), 48-57.

Harikrishnan, R., Rani, M.N. \& Balasundaram, C. (2003) Hematological and biochemical parameters in common carp, Cyprinus carpio, following herbal treatment for Aeromonas hydrophila infection. Aquaculture 221 (1), 4150.

Holeton, G. \& Randall, D. (1967) The effect of hypoxia upon the partial pressure of gases in the blood and water afferent and efferent to the gills of rainbow trout. Journal of Experimental Biology 46 (2), 317-327.

Kakoolaki, S., Akbary, P., Zorriehzahra, M.J., Salehi, H., Sepahdari, A., Afsharnasab, M., Mehrabi, M.R. \& Jadgal, S. (2016) Camellia sinensis supplemented diet enhances the innate non-specific responses, haematological parameters and growth performance in Mugil 
cephalus against Photobacterium damselae. Fish \& Shellfish Immunology (57), 379-385.

Mahmoudabadi, A.Z., Dabbagh, M.A. \& Fouladi, Z. (2007) In vitro anti-Candida activity of Zataria multiflora Boiss. Evidence-Based Complementary and Alternative Medicine 4 (3), 351-353.

Misaghi, A. \& Basti, A.A. (2007) Effects of Zataria multiflora Boiss. essential oil and nisin on Bacillus cereus ATCC 11778. Food Control 18 (9), 1043-1049.

Mohseni, M., Pourali, H.R., Kazemi, R. \& Bai, S.C. (2014) Evaluation of the optimum dietary protein level for the maximum growth of juvenile beluga (Huso huso L. 1758). Aquaculture research 45 (11), 1832-1841.

Nakhai, L.A., Mohammadirad, A., Yasa, N., Minaie, B., Nikfar, S., Ghazanfari, G., Zamani, M.J., Dehghan, G., Jamshidi, H. \& Boushehri, V.S. (2007) Benefits of Zataria multiflora Boiss in experimental model of mouse inflammatory bowel disease. Evidence-Based Complementary and Alternative Medicine 4 (1), 43-50.

Ngugi, C.C., Oyoo-Okoth, E., Mugo-Bundi, J., Orina, P.S., Chemoiwa, E.J. \& Aloo, P.A. (2015) Effects of dietary administration of stinging nettle (Urtica dioica) on the growth performance, biochemical, hematological and immunological parameters in juvenile and adult Victoria Labeo (Labeo victorianus) challenged with Aeromonas hydrophila. Fish \& shellfish immunology 44 (2), 533-541.
Raissy, M., Fakhrian, M., Jafarian, M. \& Varshoei, H. (2014) Study on the effect of some medicinal plants essential oils on non-specific immune system of sterlet (Acipenser ruthenus). Journal of Marine Biology 6 (21), 23-28.

Řehulka, J. (2000) Influence of astaxanthin on growth rate, condition, and some blood indices of rainbow trout, Oncorhynchus mykiss. Aquaculture 190 (1), 27-47.

Roche, H. \& Bogé, G. (1996) Fish blood parameters as a potential tool for identification of stress caused by environmental factors and chemical intoxication. Marine Environmental Research 41 (1), 27-43.

Saei-Dehkordi, S.S., Tajik, H., Moradi, M. \& Khalighi-Sigaroodi, F. (2010) Chemical composition of essential oils in Zataria multiflora Boiss. from different parts of Iran and their radical scavenging and antimicrobial activity. Food and Chemical Toxicology 48 (6), 1562-1567.

Shafiee, A., Javidnia, K. \& Tabatabai, M. (1999) Volatile constituents and antimicrobial activity of Zataria multiflora, population Iran. Iranian Journal of Chemistry and Chemical Engineering (IJCCE) 18 (1), 1-5.

Sharif Rohani, M., Masoumzadeh, M., Haghighi, M., Jalilpoor, J., Pourdehghani, M., Shenavar Masouleh, A., Alizadeh, M. \& Bazari Moghaddam, S. (2013) Effects of oral administration of Zataria multiflora essential oil on some blood and serum parameters in 
Acipenser persicus. Iranian Journal of activities of the essential oil and methanol Fisheries Sciences 12 (4), 908-915. extract of endemic Zataria multiflora Boiss.

Sharif Roohani, M., Haghighi, M., Assaeian, Food control 18 (7), 800-805.

H., Lashtoo Aghaee, G. R. (2007) A study of Soltani, M., Sheikhzadeh, N., Ebrahimzadehthe anesthetic effect of Zataria multiflora Boiss. (Labiatae) essence on Oncorhynchus mykiss and cultured Salmo trutta caspius. Iranian Scientific Fisheries Journal 16, 99106 (In Persian).

Mousavi, H.A. \& Zargar, A. (2010) Effects of Zataria multiflora essential oil on innate immune responses of common carp (Cyprinus carpio). Journal of Fisheries and Aquatic science 5 (3), 191-199.

Sharififar, F., Moshafi, M., Mansouri, S., Walsh, C.J. \& Luer, C.A. (2004) Elasmobranch Khodashenas, M. \& Khoshnoodi, M. (2007) In hematology: identification of cell types and vitro evaluation of antibacterial and antioxidant practical applications. 


\section{تأثير آويشن شيرازى بر خصوصيات خونى و رشدى ماهى قزل آلاى رنكين كمان}

نسرين جوبكار كروه شيلات، دانشكده كشاورزى، واحد كرمانشاه، دانشكاه آزاد اسلامى،كرمانشاه، ايران.

جكيده

آويشن شيرازى در مناطق كرم مشرق زمين، ايران، افغانستان و پاكستان مورد كشت قرار مى كيرد. هدف اين مقاله بر اين است

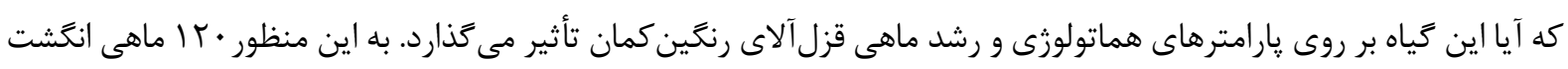

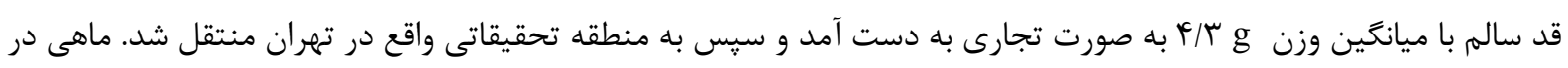
رزيمهاى غذايى حاوى

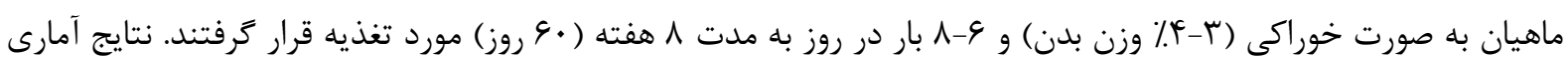
نشان داد اختلاف معنىدارى در بين ماهىهاى مختلف تغذيه شده با سطوح مختلف Z.M. در وزن متوسط وجود ندارد

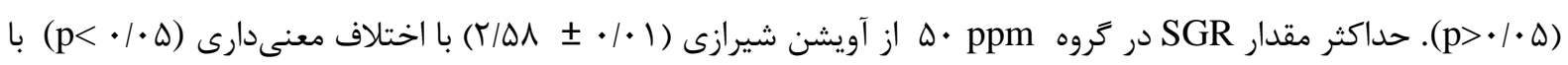

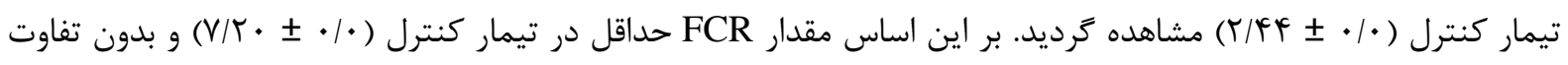

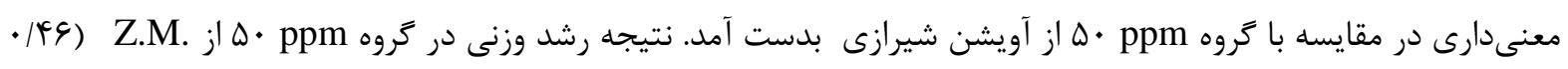

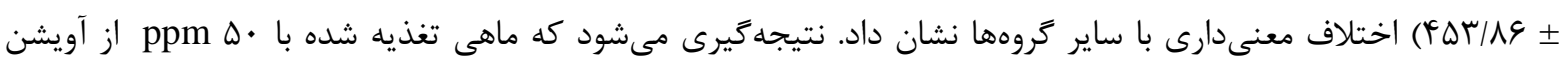
شيرازى، وزن متوسط ماهى قزل آلاى رنكَين كمان را افزايش مى دهد. از سوى ديكر، Z.M. در غلظت ppm •ـ مى لواند WBC رانسبت به شاهد و ساير تيمارها و همجنين RBC افزايش دهد، اما در بين تيمارها اختلاف معنى دارى وجود نداشت (ه • •>م). برعك، مقادير HCH Hb به طور معنىارى كمتر از سايرين بود (ه.|•>p). نتيجهكيرى مىشود كه ماهى قزل الاى رنكَين كمان تغذيه شده با ppm •ه از آويشن شيرازى، وزن متوسط ماهى قزل آلاى رنكَين كمان را افزايش مى دهد در حاليكه افزايش ايمنى ذاتى به طور معنى دارى رخ داده است.

كلمات كليدى: ماهى قزلآلاى رنخين كمان، آويشن شيرازى، وزن، شاخصهاى هماتولوزى. نويسنده مسئول: nchoobkar20@iauksh.ac.ir 